\title{
Thirty-two new cases with small supernumerary marker chromosomes detected in connection with fertility problems: Detailed molecular cytogenetic characterization and review of the literature
}

\author{
MARINA MANVELYAN ${ }^{1,2}$, MARILUCE RIEGEL ${ }^{3}$, MONICA SANTOS $^{4}$, CARME FUSTER $^{4}$, \\ FRANCK PELLESTOR ${ }^{5}$, MARIE-LUISE MAZAURIK ${ }^{6}$, BERNT SCHULZE $^{7}$, ANNA POLITYKO $^{8}$, \\ HANNE TITTELBACH $^{9}$, GISELA REISING-ACKERMANN ${ }^{10}$, BRITTA BELITZ ${ }^{11}$, UTE HEHR ${ }^{12}$, \\ CHRISTINA KELBOVA ${ }^{13}$, MARIANNE VOLLETH ${ }^{14}$, ELISABETH GÖDDE ${ }^{15}$, JASEN ANDERSON ${ }^{16}$, \\ PETER KÜPFERLING $^{17}$, SIGRID KÖHLER ${ }^{18}$, HANS-CHRISTOPH DUBA $^{19}$, ANDREAS DUFKE $^{20}$, \\ DILEK AKTAS $^{21}$, THOMAS MARTIN ${ }^{22}$, ISOLDE SCHREYER ${ }^{1}$, ELISABETH EWERS ${ }^{1}$, \\ DANIELA REICH $^{1}$, KRISTIN MRASEK $^{1}$, ANJA WEISE $^{1}$ and THOMAS LIEHR ${ }^{1}$
}

${ }^{1}$ Institute of Human Genetics and Anthropology, Kollegiengasse 10, D-07743 Jena, Germany; ${ }^{2}$ Department of Genetics and Laboratory of Cytogenetics, State University, 1, Alex Manoukian Street, Jerewan 375025, Armenia; ${ }^{3}$ Institute for Medical Genetics of the University of Zürich, Schorenstr. 16, CH-8603 Schwerzenbach, Switzerland; ${ }^{4}$ Biological and Medical Genetics Unit, Autonomous University of Barcelona, E-08193 Bellaterra, Spain; ${ }^{5}$ Institute of Human Genetics, CNRS UPR 1142, Rue de la Cardonille 141, F-34396 Montpellier Cedex 5, France; ${ }^{6}$ Practice of Prenatal Medicine and Genetics, Graf Adolf Str. 35 , D-40210 Düsseldorf; ${ }^{7}$ Practice of Human Genetics, Podbielskistr. 122, D-30177 Hannover, Germany; ${ }^{8}$ Republican Medical Center, 'Mother and Child', Orlovskayastr. 66, 220053 Minsk, Republic of Belarus; ${ }^{9}$ Practice of Human Genetics, Bankgasse 3, D-90402 Nuremberg; ${ }^{10}$ Practice of Human Genetics, Strümpellstr. 40, D-04289 Leipzig; ${ }^{11}$ Practice of Human Genetics, Frankfurter Allee 231a (MLZ), D-10365 Berlin; ${ }^{12}$ Laboratory of Human Genetics, Hemauerstr. 1, D-93047 Regensburg;

${ }^{13}$ Practice of Human Genetics, Friedrichstr. 38/40, D-01067 Dresden; ${ }^{14}$ Institute of Human Genetics, Leipziger Str. 44, D-39120 Magdeburg; ${ }^{15}$ Practice of Human Genetics, Castroper Str. 106, D-45711 Datteln, Germany; ${ }^{16}$ Department of Cytogenetics, Sullivan Nicolaides Pathology, Taringa QLD, Australia; ${ }^{17}$ Practice of Human Genetics, Marienstr. 27, D-03046 Cottbus; ${ }^{18}$ Practice of Human Genetics, Frankfurter Str. 62, D-97082 Würzburg, Germany; ${ }^{19}$ Human Genetics, Institute for Prenatal Medicine, Krankenhausstr. 26-30, A-4020 Linz, Austria; ${ }^{20}$ Institute of Human Genetics, Calwerstrasse 7, D-72076 Tübingen, Germany; ${ }^{21}$ Hacettepe University Faculty of Medicine, Department of Genetics, TR-06100 Sihhiye, Ankara, Turkey; ${ }^{22}$ Practice of Human Genetics, Kardinal-Wendel Str. 14, D-66424 Homburg, Germany

Received January 14, 2008; Accepted February 22, 2008

\begin{abstract}
Thirty-two patients with fertility problems were identified as carriers of small supernumerary marker chromosomes (sSMC). Molecular cytogenetic techniques

Correspondence to: Dr Thomas Liehr, Institut für Humangenetik und Anthropologie, Postfach, D-07740 Jena, Germany

E-mail: i8lith@mti.uni-jena.de
\end{abstract}

Key words: small supernumerary marker chromosomes, fertility problems, molecular cytogenetics, familial, de novo, euchromatic variations were used to characterize their chromosomal origin. Together with the other cases available in the literature $111 \mathrm{sSMC}$ cases have now been detected in connection with fertility problems in otherwise clinically healthy persons and characterized for their genetic content. According to this study, in $60 \%$ of the cases the sSMC originated from chromosomes 14 or 15 . Euchromatic imbalances were caused by the sSMC presence in $30 \%$ of the cases. Notably, in $53 \%$ of infertile sSMC carriers, the SSMC was parentally transmitted. As we found indications of an as yet unknown mechanism for the elimination of sSMC from the human gene pool, sSMC could also play a role in elucidating the process of chromosome gain and loss during evolution. Nonetheless, further detailed molecular analysis will be necessary in the future to characterize the mechanisms and genetic basis for this phenomenon. 


\section{Introduction}

Patients with fertility problems are known to be a clinically heterogeneous group as a variety of factors can influence fertility. Apart from hormone status, age, exercise, obesity, infectious disease, immunological or psychological factors, fertility problems can result from surgery or blockage, or be associated with defined abnormalities in the gametes, such as azoospermia or oligoasthenoteratozoospermia syndrome (OAT) $(1,2)$. Fertility problems and/or infertility are defined as the inability to conceive after one year of regular unprotected intercourse and manifest in one in six couples wishing to start a family. In about $20 \%$ of couples the reason for infertility remains 'unexplained' (2).

As most, if not all, of the aforementioned factors of infertility are likely to have genetic components it is difficult to accurately assess the corresponding genetic contribution. Nevertheless, genetic and/or karyotypic analysis has revealed the association of specific (cyto)genetic conditions with fertility problem phenotypes, such as mutations in the cystic fibrosis (CFTR) gene, mutations or microdeletions in $\mathrm{Y}$ chromosome genes, or the presence of constitutional numerical or structural chromosomal aberrations (1). The latter, such as sex chromosome aberrations, and the presence of constitutional inversions, translocations or small supernumerary marker chromosomes (sSMC) (3), can lead both to fertility problems and repeated abortions (1). The rate of sSMC presence in the normal population was recently determined to be $0.044 \%$, but elevated to $0.125 \%$ in infertile groups Distributing the latter group into male and female, there is a gender-specific 7.5:1 difference in sSMC frequency (4).

Here we present the, to our knowledge, largest molecular cytogenetic study on otherwise healthy persons with fertility problems and an sSMC. Nineteen male and 13 female carriers were studied. All of them had a history of repeated abortions, amenorrhea, unexplained infertility and/or had undergone intracytoplasmatic sperm injected treatment (ICSI). The origin and genetic content of the sSMC were characterized in detail and are discussed with the other 79 cases from the literature.

\section{Materials and methods}

Cytogenetics. All individuals included in Table I were clinically healthy, apart from fertility problems. A banding cytogenetic technique was performed according to standard procedures on peripheral blood samples (5) of the 32 patients summarized in Table I. Fifteen to 25 metaphases were analyzed per patient.

Molecular cytogenetics. The applied multicolor FISH (mFISH) approaches have also been previously described in detail: centromere-specific mFISH (cenM-FISH) (6) and subcentromere-specific mFISH (subcenM-FISH) (7) were used to characterize the sSMC (see Table I and Fig. 1).

Database search. All sSMC in infertile subjects, characterized for their chromosomal origin and reported in the literature were included in Table I. This data was obtained from the sSMC database (8).
AZF deletion status in males. Unfortunately no information was available on the AZF deletion status in male subjects reported in the literature, or in those included here as new cases.

\section{Results}

The results obtained in the 32 new sSMC cases with fertility problems are summarized, together with the data from the literature in Table I. Cases 3, 5, 7, 9, 12, 16-23, 32-38, 69, $71,72,74,75,81,96,103,104,110$ and 111 are reported here for the first time and were characterized comprehensively for their chromosomal origin and genetic content by cenMand subcenM-FISH. Examples of sSMC characterization are given in Fig. 1 for cases 7, 17 and 37.

Together with the 79 other cases from the literature (8), making a total of 111 cases, the sSMC detected due to fertility problems were characterized for their chromosomal origin. Examples for all 24 human chromosomes apart from chromosomes 4, 10, 11, 13, 19 and $\mathrm{X}$ were found (Fig. 2a). In the majority the $\mathrm{SSMC}$ derived from an acrocentric chromosome. Overall, $60 \%$ of the sSMC cases originated from chromosomes 15 or 14 (Fig. 2b).

Apart from cases 11, 14, 24, 40-45, 82-93, 97, 98, 105 and 109 , all sSMC were characterized in detail for their genetic content. The euchromatic regions showing imbalances due to sSMC presence are summarized in Fig. 2c. For case 10 euchromatin was also detected in an $\operatorname{sSMC}(6)$, however, no imbalances were induced by sSMC presence, as there was a corresponding deletion of a chromosome 6 .

The reasons for which the cytogenetic studies were performed in the 111 patients are listed by case in Table I, and summarized in Fig. 3a. In Figs. 3-6 the cases were divided into four groups as follows: (i) OAT, comprised of males with oligoasthenoteratozoospermia or similar fertility problems associated with numerically and/or morphologically altered sperm; (ii) 'amenorrhea', comprised of females suffering from amenorrhea or similar clinical conditions; (iii) RAB, comprised of patients with repeated abortions in partnership, and (iv) FP, comprising the remainder with 'unexplained infertility'. In Fig. 3a these groups are separated by gender. Overall, the most common indication was 'unexplained infertility/fertility problems' (FP), followed by 'repeated abortions' (RAB), OAT syndrome/azoospermia, and amenorrhea. As seen in Fig. 3b amenorrhea and defined abnormalities in the gametes are more likely to appear when the sSMC originates from an acrocentric chromosome. Repeated abortions and unexplained infertility were found in about the same frequency in both groups.

The parental origin incidence of $\mathrm{sSMC}$ in cases with fertility problems is summarized in Fig. 4; the relevant information was available for 36 of the cases in Table I. Unexpectedly, $53 \%$ of the sSMC detected in connection with fertility problems were derived from the parents. Maternally derived sSMC occurred 1.6 times more frequently than paternally derived sSMC (Fig. 4). Eighty-eight percent of the inherited sSMC were derived from an acrocentric chromosome (see Table I). In so-called 'familial cases' the sSMC was proven to have been carried through more than one generation; but either no information on paternal or 

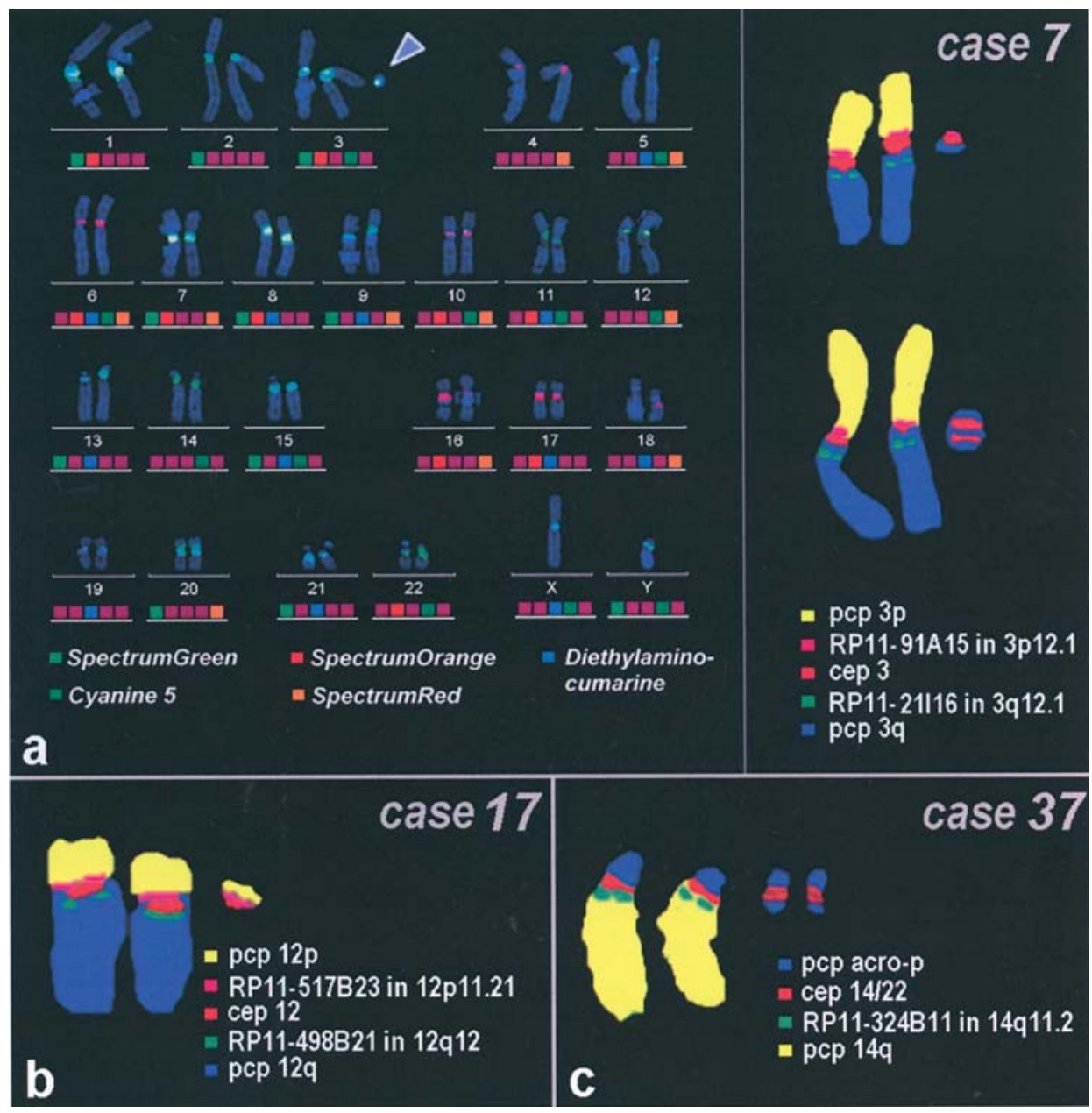

Figure 1. Examples of results obtained by cenM-FISH and subcenM-FISH in cases 7, 17 and 37, according to Table I. (a) cenM-FISH (left) revealed that the sSMC in case 7 originated from chromosome 3 (arrowhead); subcenM-FISH (right) demonstrated that there was a mosaic karyotype, min(3)(:p12.1$>$ q11.1 11.2:) [55]/min(3)(:p11.1->q11.1 11.2::q11.1 11.2->p11.1:)[2]. (b) and (c) subcenM-FISH characterized in case 17 a min(12)(:p12.1 12.2->q10:) and in case 37 two identical inv dup(14)(q11.1). cep, centromeric probe; $p$, short arm; pcp, partial chromosome painting probe; q, long arm.

maternal passage was provided, or it changed from grandpaternal to maternal (case 77).

In patients with fertility problems there is a tendency towards gender-specific differences in the offspring (Fig. 5a): a maternally inherited sSMC is more likely to lead to fertility problems in sons than in daughters and vice versa for father and daughter. All inherited SSMC cases not detected in connection with fertility problems are summarized in Fig. 5b, and a nearly $1: 1$ sex ratio in the resulting children can be observed.

There is also a tendency towards repeated abortions and OAT in inherited compared to de novo SSMC (Fig. 6).

\section{Discussion}

Chromosomal origin of sSMC in infertile patients. In the present study 32 new sSMC patients with fertility problems were added to 79 single-case reports from the literature. The SSMC were characterized for their chromosomal origin for all 111 cases. At present an involvement of only 19 of the 24 human chromosomes has been described in connection with fertility problems and sSMC-formation. Before the present study no sSMC[5] or sSMC[12] had been reported within this group of patients. Thus, as soon as more cases are comprehensively characterized, it is to be expected that examples for the remaining 5 chromosomes will also be observed in patients with fertility problems.

In cases 110 and 111 the exact chromosomal origin could not be determined; as the sSMC were stainable only by a probe specific for the acrocentric p-arms they were described as inv dup(acro). In these two cases the amount of alphoid DNA sequences on the SSMC was too small to be detected by FISH. A similar observation was previously described for a case of an sSMC[5] (9). In the latter the presence of D1/5/19Z1 sequences was confirmed by microdissection and reverse FISH. This approach could not be applied in the present cases due to lack of material.

In $78 \%$ of the cases with fertility problems summarized here, the sSMC derived from an acrocentric chromosome (Table I and Fig. 2a). Even focusing only on parentally derived sSMC (see below), $88 \%$ of the cases were derived from an acrocentric chromosome (Table I). This rate is similar for the overall population [ $70 \%$ according to (3)]. Also it was not unexpected that $\mathrm{SSMC}[15]$ was the most frequently observed $(4,8)$. However, the SSMC[14] rate in the infertile patients from the present study was, at $15 \%, \sim 4$ times higher 

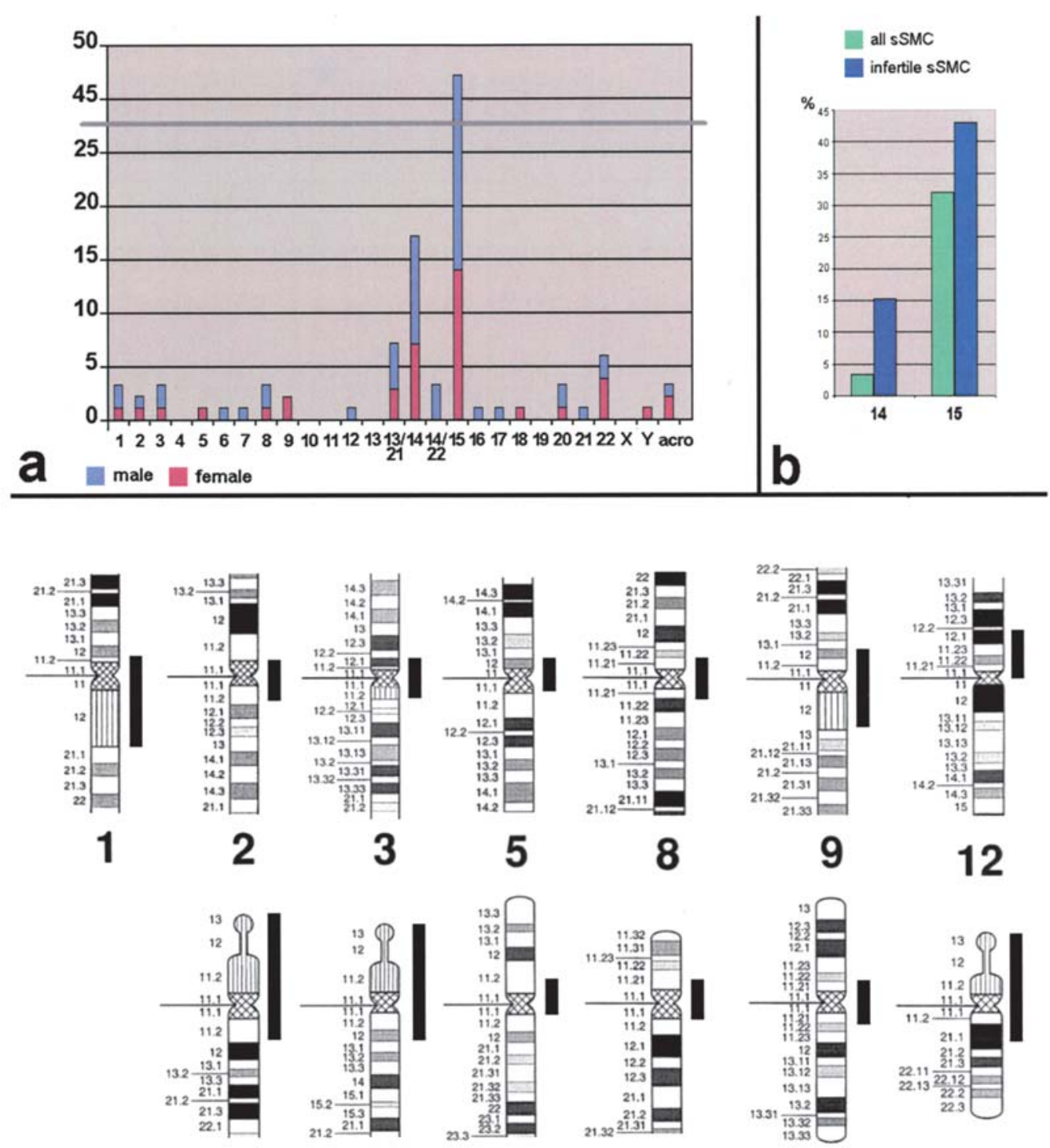

C

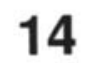

15

17

18

20

21

Figure 2. (a) Chromosomal distribution of sSMC in infertile patients depicted by gender, based on the data from Table I. (b) Percentage of sSMC[14] and sSMC [15] according to (8) (green bars) compared to the rate of the corresponding chromosomes in infertile patients (blue bars). Chromosome 14 is clearly over-represented among the latter. (c) Ideograms of the centromere-near regions of chromosomes 1-3, 5, 8, 9, 12, 14, 15, 17, 18, 20 and 21. The black bars show the maximal size of imbalances detected in the 111 patients with fertility problems, i.e. chromosomal regions for which a causative connection to fertility problems cannot completely be disregarded.

than in all sSMC cases studied for their chromosomal origin $(3,4,8)$ (Fig. 2b). At present there is no explanation for this observation. Nonetheless it can be concluded, that after SSMC detection in connection with unexplained infertility in $\sim 60 \%$ of cases the origin of the sSMC can be characterized by application of the centromere-specific probes for chromosomes 14 and 15 .

Genetic content of sSMC in infertile. Eighty-seven of the 111 sSMC cases summarized in Table I were characterized comprehensively for their genetic content. In summary, no genetic imbalance was present in $70 \%$ of the cases, since exclusively heterochromatic material was detected on the sSMC. Small centomere-near partial tri-, tetra- or even hexasomies were observed in the remaining $30 \%$ of the cases. Euchromatin, and thus, an imbalance could be caused by any of the 13 chromosomes depicted in Fig. 2c. It is well known that euchromatic imbalances do not necessarily lead to clinical effects (10). This has also been reported specifically for sSMC (11). However, a contribution of at least some of these regions to infertility/fertility problems cannot be disregarded at present.

Parental origin of the sSMC. As summarized in Fig. 4, 53\% of the sSMC detected in connection with fertility problems were derived from one of the parents; for two of these cases euchromatin presence was proven (cases 59-60). Maternally derived SSMC occurred more frequently than paternally derived SSMC, an observation consistent with the recently outlined fact that familial sSMC are predominantly inherited 

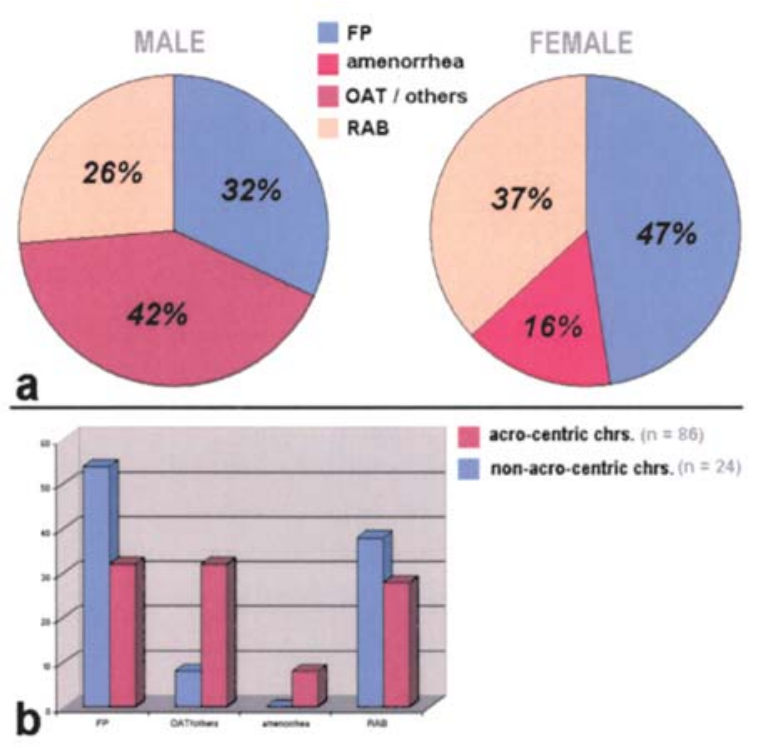

Figure 3. Distribution of reasons for fertility problems in the 111 patients with sSMC, divided by gender (a) and by chromosomal origin (b). Due to the small number of cases available only a distinction between acrocentricand non-acrocentric-derived chromosomes was possible. FP, cases with unexplained infertility; n, number of cases; OAT, oligoasthenoteratozoospermia syndrome; others, other defined abnormalities in the gametes (e.g. azoospermia); RAB, repeated abortions.

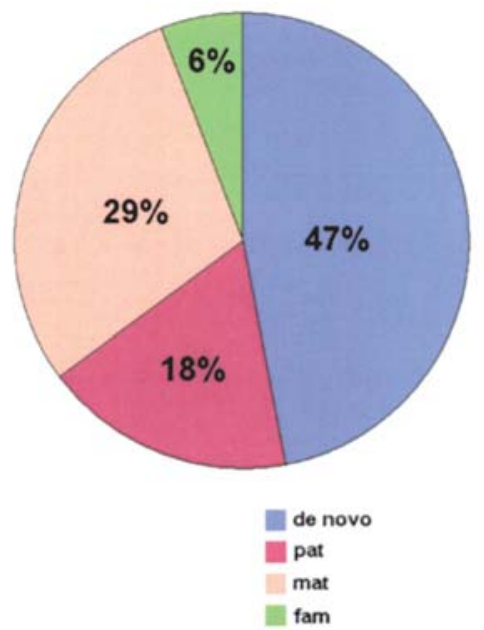

Figure 4. Parental origin of the sSMC in 36 of the 111 cases listed in Table I, where corresponding information was available. fam, familial; mat, maternal; pat, paternal.

via the maternal line (12). Unfortunately, no information was available as to whether fertility problems were already present in the parents of the sSMC carriers who had inherited an sSMC from one of the parents.

According to population studies otherwise healthy persons with unexplained infertility have a $\sim 2.9$-fold enhanced risk for detection of an sSMC during cytogenetic analysis compared to the general population (13). Thus, the fact that familial sSMC can be detected in connection with fertility problems in $>50 \%$ was unexpected.

Analyzing this finding further (Figs. 5-6) there appeared to be gender-specific differences for the children: a maternally

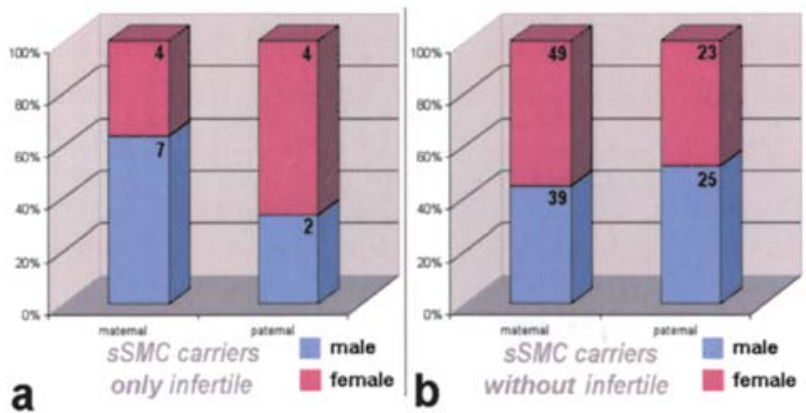

Figure 5. Infertile carriers of an inherited sSMC according to Table I (a), compared in a gender-specific way with all other carriers of an inherited sSMC according to (8) (b). The absolute number of available cases for this comparison is given in small black numbers in the right upper edge of the differentially colored column fields.

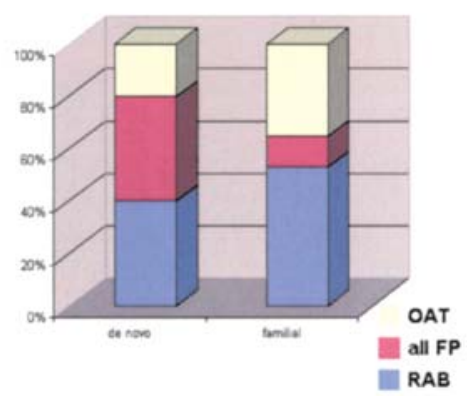

Figure 6 . The cases from Table I separated by their origin into familial and de novo cases and aligned with the clinical reason for the cytogenetic studies. all FP, cases with unexplained infertility including amenorrhea; OAT, oligoasthenoteratozoospermia syndrome and other defined abnormalities in the gametes (e.g. azoospermia); RAB, repeated abortions.

inherited sSMC was more likely to be detected in a son with fertility problems than in daughters and vice versa for paternally inherited sSMC. Even though the available data is small (17 cases in infertile sSMC carriers) the tendency seems to be clear compared to carriers of familial sSMC detected due to reasons other than fertility problems (Fig. 5).

As demonstrated in Fig. 6 compared to de novo sSMC there is also a slight tendency towards repeated abortions or OAT in inherited sSMC.

Reasons for fertility problems in the studied sSMC carriers. The mechanisms by which sSMC presence influences fertility are not really understood at present. However, for cases 10 , 108 and 109 , it can be speculated that the chromosomal aberration led to an even more imbalanced, and subsequently unviable, situation in the potential offspring, than that present in the sSMC carriers themselves.

For the other cases a direct correlation of sSMC presence and fertility problems is not easy to evoke, especially, as for most cases, no clear clinical indication is provided: in most cases the diagnosis was 'unexplained infertility/fertility problems' (32-47\% in male and female) or repeated abortions in partnership (26-37\%, see Fig. 3a). Overall, different kinds of sSMC are detectable in the heterogeneous group of 
Table I. All cases with well defined sSMC detected in otherwise normal patients with fertility problems as characterized in this study and available from the literature. ${ }^{\mathrm{a}}$

\begin{tabular}{|c|c|c|c|c|c|}
\hline $\begin{array}{l}\text { Case } \\
\text { no. }\end{array}$ & GTG-result & $\begin{array}{l}\text { Parental } \\
\text { origin }\end{array}$ & FISH result & Clinical findings & $\begin{array}{l}\text { sSMC no. } \\
\text { according to ( } 8)\end{array}$ \\
\hline 1 & $47, \mathrm{XY},+\operatorname{mar}[100 \%]$ & de novo & $\mathrm{r}(1)(:: \mathrm{p} 11->\mathrm{q} 11::)$ & $\mathrm{RAB}$ in female partner & 01-O-p11.1/1-2 \\
\hline 2 & $\begin{array}{l}47, \mathrm{XX},+\operatorname{mar}[40 \%] / \\
46, \mathrm{XX}[60 \%]\end{array}$ & de novo & r(1)(::p11->q11::) & FP & 01-O-p11.1/1-3 \\
\hline $3^{\mathrm{b}}$ & $47, \mathrm{XY},+\operatorname{mar}[100 \%]$ & n.a. & $\min (1)(: \mathrm{p} 11.2->\mathrm{q} 12:)$ & $\mathrm{RAB}$ in female partner & 01-O-p11.1/3-1 \\
\hline 4 & $\begin{array}{l}47, \mathrm{XY},+\operatorname{mar}[52 \%] / \\
46, \mathrm{XY}[48 \%]\end{array}$ & de novo & $\mathrm{r}(2)(:: \mathrm{p} 11.1->\mathrm{q} 11.2::)$ & FP, ICSI & 02-O-p11.1/1-1 \\
\hline $5^{b}$ & $\begin{array}{l}47, \mathrm{XX},+\operatorname{mar}[60 \%] / \\
46, \mathrm{XX}[40 \%]\end{array}$ & n.a. & $\begin{array}{l}\mathrm{r}(2)(:: \mathrm{p} 11.1->\mathrm{q} 11.2::)[7] / \\
\mathrm{r}(2 ; 2)(:: \mathrm{p} 11.1->\mathrm{q} 11.2: \\
: \mathrm{p} 11.1->\mathrm{q} 11.2::)[2]\end{array}$ & FP & 02-O-p11.1/1-3 \\
\hline 6 & $47, \mathrm{XY},+\operatorname{mar}[100 \%]$ & n.a. & $\min (3)(: p 12.2->q 11.1:)$ & FP, ICSI & 03-O-p12.2/1-1 \\
\hline $7^{\mathrm{b}}$ & $\begin{array}{l}47, \mathrm{XY},+\operatorname{mar}[30 \%] / \\
46, \mathrm{XY}[70 \%]\end{array}$ & n.a. & $\begin{array}{l}\min (3)(: \mathrm{p} 12.1->\mathrm{q} 11.1 \sim 11.2:)[55] / \\
\min (3)(: \mathrm{p} 11.1->\mathrm{q} 11.1 \sim 11.2 \\
:: \mathrm{q} 11.1 \sim 11.2->\mathrm{p} 11.1:)[2]\end{array}$ & $\begin{array}{l}\text { FP with cryptorchidism, } \\
\text { small testes, umbilical } \\
\text { and inguinal hernia. }\end{array}$ & 03-O-p12.1/1-1 \\
\hline 8 & $\begin{array}{l}47, \mathrm{XX},+\operatorname{mar}[20 \%] / \\
46, \mathrm{XX}[80 \%]\end{array}$ & n.a. & $\mathrm{r}(3)$ & RAB & 03-CO-3 \\
\hline $9^{b}$ & $47, \mathrm{XX},+\operatorname{mar}[100 \%]$ & n.a. & $\min (5)(: \mathrm{p} 12->\mathrm{q} 11.1:)$ & FP, ICSI & 05-O-p12/1-1 \\
\hline 10 & $\begin{array}{l}47, X Y, \operatorname{del}(6)(\mathrm{p} 22.3 \mathrm{q} 10) \\
+\mathrm{r}(6)(:: \mathrm{p} 22.3 \mathrm{q} 10::)[100 \%]\end{array}$ & n.a. & $\mathrm{r}(6)(:: \mathrm{p} 22.3->\mathrm{q} 10::)$ & FP & 06-O-p22.3/1-1 \\
\hline 11 & $\begin{array}{l}47, \mathrm{XY},+\operatorname{mar}[? \%] / \\
46, \mathrm{XY}[? \%]\end{array}$ & de novo & $\operatorname{dic}(7)$ & FP & 07-CO-1 \\
\hline $12^{\mathrm{b}}$ & $\begin{array}{l}47, \mathrm{XY},+\operatorname{mar}[40 \%] / \\
46, \mathrm{XY}[60 \%]\end{array}$ & n.a. & $\begin{array}{l}\min (8)(: p 11.1->\mathrm{q} 11.21:)[9] / \\
\min (8)(: \mathrm{p} 11.21->\mathrm{q} 11.1:)[5]\end{array}$ & FP, ICSI & 08-O-p11.1/1-1 \\
\hline 13 & $\begin{array}{l}47, \mathrm{XY},+\operatorname{mar}[45 \%] / \\
46, \mathrm{XY}[55 \%]\end{array}$ & de novo & $\mathrm{r}(8)(:: \mathrm{p} 10->\mathrm{q} 12::)$ & $\mathrm{RAB}$ in female partner & 08-O-p10/1-1 \\
\hline 14 & $\begin{array}{l}47, \mathrm{XX},+\operatorname{mar}[? \%] / \\
46, \mathrm{XX}[? \%]\end{array}$ & n.a. & $\operatorname{mar}(8)$ & $\mathrm{RAB}$ & 08-CO-3 \\
\hline 15 & $\begin{array}{l}47, \mathrm{XX},+\operatorname{mar}[75 \%] / \\
46, \mathrm{XX}[25 \%]\end{array}$ & de novo & r(9)(::p12->q10::) & $\mathrm{RAB}$ & 09-O-p12/1-2 \\
\hline $16^{\mathrm{b}}$ & $\begin{array}{l}47, \mathrm{XX},+\operatorname{mar}[? \%] / \\
46, \mathrm{XX}[? \%]\end{array}$ & de novo & $\begin{array}{l}\min (9)(: \mathrm{p} 12->\mathrm{q} 12:)[1] / \\
\min (9)(: \mathrm{p} 12->\mathrm{q} 12:: \mathrm{q} 12->\mathrm{p} 12:)[5] / \\
\mathrm{r}(9)(:: \mathrm{p} 12->\mathrm{q} 12::)[2] / \\
\mathrm{r}(9)(:: \mathrm{p} 12->\mathrm{q} 12:: \mathrm{p} 12->\mathrm{q} 12::) \times 2[1]\end{array}$ & $\mathrm{RAB}$ & 09-O-p12/3-1 \\
\hline $17^{b}$ & $\begin{array}{l}47, \mathrm{XY},+\operatorname{mar}[66 \%] / \\
46, \mathrm{XY}[34 \%]\end{array}$ & n.a. & $\min (12)(: \mathrm{p} 12.1 \sim 12.2->\mathrm{q} 10:)$ & FP, ICSI & 12-O-p12.1 12.2/1-1 \\
\hline $18^{\mathrm{b}}$ & $47, \mathrm{XY},+\operatorname{mar}[100 \%]$ & n.a. & inv dup(13or21)(q10) & FP, ICSI & 13/21-O-q10/1-3 \\
\hline $19^{b}$ & $\begin{array}{l}47, \mathrm{XX},+\operatorname{mar}[50 \%] / \\
46, \mathrm{XX}[50 \%]\end{array}$ & n.a. & $\min (13$ or 21$)(q 10)$ & $\mathrm{FP}, \mathrm{ICSI}$ & $13 / 21-\mathrm{O}-\mathrm{q} 10 / 2-2$ \\
\hline $20^{\mathrm{b}}$ & $47, \mathrm{XY},+\operatorname{mar}[100 \%]$ & n.a. & $\begin{array}{l}\text { inv dup(13)(q11) or } \\
\text { inv dup (21)(q11.1) }\end{array}$ & FP & 13/21-O-q11/2-2 \\
\hline $21^{\mathrm{b}}$ & $47, X X,+\operatorname{mar}[100 \%]$ & n.a. & $\begin{array}{l}\text { inv dup(13)(q11) or } \\
\text { inv dup (21)(q11.1) }\end{array}$ & RAB & $13 / 21-O-q 11 / 2-3$ \\
\hline $22^{\mathrm{b}}$ & $47, X Y,+\operatorname{mar}[100 \%]$ & n.a. & $\begin{array}{l}\text { inv dup(13)(q11) or } \\
\text { inv dup (21)(q11.1) }\end{array}$ & $\mathrm{RAB}$ in female partner & 13/21-O-q11/2-4 \\
\hline $23^{\mathrm{b}}$ & $47, X Y,+\operatorname{mar}[100 \%]$ & n.a. & $\begin{array}{l}\text { inv dup(13)(q11) or } \\
\text { inv dup (21)(q11.1) }\end{array}$ & OAT & 13/21-O-q11/2-6 \\
\hline 24 & $47, \mathrm{XX},+\operatorname{mar}[100 \%]$ & n.a. & $\operatorname{mar}(13$ or 21$)$ & RAB & 13/21-CO-5 \\
\hline 25 & 47,XY,+mar[100\%] & de novo & $\operatorname{inv} \operatorname{dup}(14)(\mathrm{q} 10)$ & FP, ICSI & $14-O-q 10 / 1-2$ \\
\hline 26 & $47, \mathrm{XY},+\operatorname{mar}[100 \%]$ & n.a. & $\operatorname{inv} \operatorname{dup}(14)(q 10)$ & OAT. ICSI & $14-\mathrm{O}-\mathrm{q} 10 / 1-3$ \\
\hline 27 & $47, \mathrm{XY},+\operatorname{mar}[100 \%]$ & n.a. & inv dup(14)(q10) & OAT, ICSI & $14-\mathrm{O}-\mathrm{q} 10 / 1-4$ \\
\hline 28 & $47, \mathrm{XY},+\operatorname{mar}[100 \%]$ & n.a. & inv dup(14)(q10) & OAT & $14-\mathrm{O}-\mathrm{q} 10 / 1-13$ \\
\hline
\end{tabular}


Table I. Continued.

\begin{tabular}{|c|c|c|c|c|c|}
\hline $\begin{array}{l}\text { Case } \\
\text { no. }\end{array}$ & GTG-result & $\begin{array}{l}\text { Parental } \\
\text { origin }\end{array}$ & FISH result & Clinical findings & $\begin{array}{l}\text { sSMC no. } \\
\text { according to (8) }\end{array}$ \\
\hline 29 & $47, \mathrm{XY},+\operatorname{mar}[100 \%]$ & n.a. & $\operatorname{inv} \operatorname{dup}(14)(q 10)$ & FP & 14-O-q10/1-14 \\
\hline 30 & $\begin{array}{l}47, \mathrm{XX},+\operatorname{mar}[86 \%] / \\
46, \mathrm{XX}[14 \%]\end{array}$ & n.a. & $\operatorname{inv} \operatorname{dup}(14)(q 11.1)$ & FP, ICSI & 14-O-q11.1/1-1 \\
\hline 31 & $47, \mathrm{XX},+\operatorname{mar}[100 \%]$ & n.a. & $\operatorname{inv} \operatorname{dup}(14)(q 11.1)$ & FP & 14-O-q11.1/1-2 \\
\hline $32^{\mathrm{b}}$ & $47, \mathrm{XY},+\operatorname{mar}[100 \%]$ & n.a. & $\operatorname{inv} \operatorname{dup}(14)(q 11.1)$ & OAT & 14-O-q11.1/1-3 \\
\hline $33^{b}$ & $47, \mathrm{XY},+\operatorname{mar}[100 \%]$ & n.a. & $\operatorname{inv} \operatorname{dup}(14)(q 11.1)$ & FP, ICSI & 14-O-q11.1/1-6 \\
\hline $34^{\mathrm{b}}$ & $47, \mathrm{XY},+\operatorname{mar}[100 \%]$ & n.a. & $\operatorname{inv} \operatorname{dup}(14)(q 11.1)$ & RAB & 14-O-q11.1/1-8 \\
\hline $35^{b}$ & $47, \mathrm{XX},+\operatorname{mar}[100 \%]$ & Maternal & $\operatorname{inv} \operatorname{dup}(14)(q 11.1)$ & RAB & 14-O-q11.1/1-10 \\
\hline $36^{\mathrm{b}}$ & $47, \mathrm{XY},+\operatorname{mar}[100 \%]$ & n.a. & $\operatorname{inv} \operatorname{dup}(14)(q 11.1)$ & FP & 14-O-q11.1/1-11 \\
\hline $37^{b}$ & $48, X X,+2 \operatorname{mar}[100 \%]$ & n.a. & $\operatorname{inv} \operatorname{dup}(14)(q 11.1)$ & Amenorrhea & 14-O-q11.1/2-2 \\
\hline $38^{\mathrm{b}}$ & $\begin{array}{l}47, \mathrm{XX},+\operatorname{mar}[40 \%] / \\
46, \mathrm{XX}[60 \%]\end{array}$ & n.a. & $\min (14)($ pter->q11.2:) & Oligomenorrhea & 14-O-q11.2/3-1 \\
\hline 39 & $47, \mathrm{XY},+\operatorname{mar}[100 \%]$ & n.a. & $\mathrm{r}(14)(:: \mathrm{p} 11.2->\mathrm{q} 11.2::)$ & FP, oligospermia & 14-O-q11.2/4-1 \\
\hline 40 & $47, \mathrm{XX},+\operatorname{mar}[100 \%]$ & n.a. & $\operatorname{mar}(14)$ & FP & $14-\mathrm{CO}-10$ \\
\hline 41 & $47, \mathrm{XX},+\operatorname{mar}[100 \%]$ & de novo & $\operatorname{mar}(14)$ & Amenorrhea & 14-CO-11 \\
\hline 42 & $47, \mathrm{XY},+\operatorname{mar}[100 \%]$ & n.a. & $\operatorname{mar}(14$ or 22$)$ & OAT & 14/22-CO-11 \\
\hline 43 & $47, \mathrm{XY},+\operatorname{mar}[100 \%]$ & n.a. & $\operatorname{mar}(14$ or 22$)$ & FP in female partner & 14/22-CO-29 \\
\hline 44 & $47, \mathrm{XY},+\operatorname{mar}[100 \%]$ & n.a. & $\operatorname{mar}(14$ or 22$)$ & Astenozoospermia & 14/22-CO-30 \\
\hline 45 & 47,XY,+mar[?\%] & n.a. & $\operatorname{mar}(14$ or 22$)$ & $\mathrm{RAB}$ in female partner & 14/22-CO-31 \\
\hline 46 & $47, \mathrm{XY},+\operatorname{mar}[100 \%]$ & de novo & inv dup(15)(q10) & RAB & $15-O-q 10 / 1-2$ \\
\hline 47 & $47, \mathrm{XY},+\operatorname{mar}[100 \%]$ & n.a. & inv $\operatorname{dup}(15)(q 11)$ & $\mathrm{RAB}$ in female partner & $15-\mathrm{O}-\mathrm{q} 11 / 1-18$ \\
\hline 48 & $47, \mathrm{XX},+\operatorname{mar}[100 \%]$ & n.a. & $\operatorname{inv} \operatorname{dup}(15)(q 11)$ & RAB & 15-O-q11/1-19 \\
\hline 49 & $47, \mathrm{XX},+\operatorname{mar}[100 \%]$ & n.a. & $\operatorname{inv} \operatorname{dup}(15)(q 11)$ & RAB & $15-\mathrm{O}-\mathrm{q} 11 / 1-20$ \\
\hline 50 & $47, \mathrm{XX},+\operatorname{mar}[100 \%]$ & Paternal & $\operatorname{inv} \operatorname{dup}(15)(q 11)$ & Amenorrhea & $15-\mathrm{O}-\mathrm{q} 11 / 1-21$ \\
\hline 51 & $47, \mathrm{XX},+\operatorname{mar}[100 \%]$ & Paternal & $\operatorname{inv} \operatorname{dup}(15)(q 11)$ & RAB & $15-\mathrm{O}-\mathrm{q} 11 / 1-23$ \\
\hline 52 & $47, \mathrm{XX},+\operatorname{mar}[100 \%]$ & n.a. & $\operatorname{inv} \operatorname{dup}(15)(q 11)$ & FP & $15-\mathrm{O}-\mathrm{q} 11 / 1-26$ \\
\hline 53 & $47, \mathrm{XY},+\operatorname{mar}[100 \%]$ & n.a. & $\operatorname{inv} \operatorname{dup}(15)(q 11)$ & FP & $15-\mathrm{O}-\mathrm{q} 11 / 1-31$ \\
\hline 54 & $47, \mathrm{XX},+\operatorname{mar}[100 \%]$ & Paternal & $\operatorname{inv} \operatorname{dup}(15)(q 11)$ & RAB & $15-\mathrm{O}-\mathrm{q} 11 / 1-33$ \\
\hline 55 & $47, \mathrm{XY},+\operatorname{mar}[100 \%]$ & n.a. & $\operatorname{inv} \operatorname{dup}(15)(q 11)$ & FP, ICSI & $15-\mathrm{O}-\mathrm{q} 11 / 1-34$ \\
\hline 56 & $47, \mathrm{XY},+\operatorname{mar}[100 \%]$ & n.a. & inv dup(15)(q11) & FP, ICSI & 15-O-q11/1-35 \\
\hline 57 & $47, \mathrm{XY},+\operatorname{mar}[100 \%]$ & n.a. & $\operatorname{inv} \operatorname{dup}(15)(q 11)$ & OAT & 15-O-q11/1-37 \\
\hline 58 & $48, X Y,+2 \operatorname{mar}[100 \%]$ & $\begin{array}{l}\text { Maternal } \\
\text { (1 sSMC only) }\end{array}$ & $\operatorname{inv} \operatorname{dup}(15)(q 11) \times 2$ & RAB & $15-O-q 11 / 2-1$ \\
\hline 59 & $48, \mathrm{XX},+2 \operatorname{mar}[100 \%]$ & $\begin{array}{l}\text { Paternal } \\
\text { (1 sSMC only) }\end{array}$ & $\operatorname{inv} \operatorname{dup}(15)(q 11) \times 2$ & FP & $15-\mathrm{O}-\mathrm{q} 11 / 2-2$ \\
\hline 60 & $48, \mathrm{XX},+2 \operatorname{mar}[100 \%]$ & de novo & $\operatorname{inv} \operatorname{dup}(15)(\mathrm{q} 11) \mathrm{x} 2$ & FP & $15-\mathrm{O}-\mathrm{q} 11 / 2-3$ \\
\hline 61 & $47, \mathrm{XY},+\operatorname{mar}[100 \%]$ & n.a. & $\min (15)(\mathrm{p} 11->\mathrm{q} 11)$ & Oligospermia & $15-O-q 11 / 4-1$ \\
\hline 62 & $\begin{array}{l}47, \mathrm{XX},+\operatorname{mar}[? \%] / \\
46, \mathrm{XX}[? \%]\end{array}$ & n.a. & $\operatorname{inv} \operatorname{dup}(15)(q 11.1)$ & $\mathrm{FP}, \mathrm{ICSI}$ & 15-O-q11.1/1-1 \\
\hline 63 & $47, \mathrm{XX},+\operatorname{mar}[100 \%]$ & n.a. & $\operatorname{inv} \operatorname{dup}(15)(q 11.1)$ & Amenorrhea & 15-O-q11.1/1-6 \\
\hline 64 & $47, \mathrm{XY},+\operatorname{mar}[100 \%]$ & Maternal & $\operatorname{inv} \operatorname{dup}(15)(q 11.1)$ & Azoospermia & 15-O-q11.1/1-35 \\
\hline 65 & $47, \mathrm{XY},+\operatorname{mar}[100 \%]$ & Maternal & $\operatorname{inv} \operatorname{dup}(15)(q 11.1)$ & Azoospermia & 15-O-q11.1/1-36 \\
\hline 66 & $47, \mathrm{XY},+\operatorname{mar}[100 \%]$ & Maternal & $\operatorname{inv} \operatorname{dup}(15)(q 11.1)$ & Azoospermia & $15-O / q 11.1 / 1-37$ \\
\hline 67 & $47, \mathrm{XY},+\operatorname{mar}[100 \%]$ & Paternal & $\operatorname{inv} \operatorname{dup}(15)(q 11.1)$ & OAT, seminoma & 15-O-q11.1/1-38 \\
\hline 68 & $47, \mathrm{XY},+\operatorname{mar}[100 \%]$ & de novo & $\operatorname{inv} \operatorname{dup}(15)(q 11.1)$ & Azoospermia & 15-O-q11.1/1-39 \\
\hline $69^{\mathrm{b}}$ & $47, \mathrm{XY},+\operatorname{mar}[100 \%]$ & n.a. & $\operatorname{inv} \operatorname{dup}(15)(q 11.1)$ & OAT & 15-O-q11.1/1-41 \\
\hline 70 & $47, \mathrm{XY},+\operatorname{mar}[100 \%]$ & Familial & $\operatorname{inv} \operatorname{dup}(15)(q 11.1)$ & OAT (familial) & 15-O-q11.1/1-42 \\
\hline $71^{\mathrm{b}}$ & 47,XX,+mar[?100\%] & n.a. & $\operatorname{inv} \operatorname{dup}(15)(q 11.1)$ & Primary amenorrhea & 15-O-q11.1/1-45 \\
\hline
\end{tabular}


Table I. Continued.

\begin{tabular}{|c|c|c|c|c|c|}
\hline $\begin{array}{l}\text { Case } \\
\text { no. }\end{array}$ & GTG-result & $\begin{array}{l}\text { Parental } \\
\text { origin }\end{array}$ & FISH result & Clinical findings & $\begin{array}{l}\text { sSMC no. } \\
\text { according to (8) }\end{array}$ \\
\hline $72^{\mathrm{b}}$ & $\begin{array}{l}47, \mathrm{XX},+\operatorname{mar}[23 \%] / \\
46, \mathrm{XX}[77 \%]\end{array}$ & n.a. & $\operatorname{inv} \operatorname{dup}(15)(q 11.1)$ & RAB & 15-O-q11.1/1-46 \\
\hline 73 & $\begin{array}{l}48, \mathrm{XX},+2 \mathrm{mar}[80 \%] / \\
46, \mathrm{XX}[20 \%]\end{array}$ & de novo & $2 x \operatorname{inv} \operatorname{dup}(15)(q 11.1)$ & RAB (familial) & 15-O-q11.1/2-1 \\
\hline $74^{\mathrm{b}}$ & $48, \mathrm{XY},+2 \operatorname{mar}[100 \%]$ & Maternal & $2 x \operatorname{inv} \operatorname{dup}(15)(q 11.1)$ & Oligospermia & 15-O-q11.1/2-2 \\
\hline $75^{\mathrm{b}}$ & $\begin{array}{l}\text { 47,XY,+mar[?\%]/ } \\
46, \mathrm{XY}[? \%]\end{array}$ & n.a. & $\mathrm{r}(15)(:: \mathrm{p} 1 ? 2->\mathrm{q} 11.1::)$ & Severe OAT, ICSI & 15-O-q11.1/5-1 \\
\hline 76 & $47, \mathrm{XY},+\operatorname{mar}[100 \%]$ & Familial & $\operatorname{inv} \operatorname{dup}(15)(q 11.2)$ & Oligospermia & 15-O-q11.2/1-4 \\
\hline 77 & $47, \mathrm{XX},+\operatorname{mar}[100 \%]$ & $\begin{array}{l}\text { Maternal and } \\
\text { grandpaternal }\end{array}$ & $\operatorname{inv} \operatorname{dup}(15)(q 11.2)$ & RAB & $15-\mathrm{O}-\mathrm{q} 11.2 / 1-5$ \\
\hline 78 & $48, \mathrm{XY},+2 \operatorname{mar}[100 \%]$ & n.a. & $\operatorname{inv} \operatorname{dup}(15)(q 11.2) \times 2$ & OAT & 15-O-q11.2/3-2 \\
\hline 79 & $\begin{array}{l}47, \mathrm{XY},+\operatorname{mar}[98 \%] / \\
46, \mathrm{XY}[2 \%]\end{array}$ & n.a. & $\min (15)(: p 13->q 11.2:)$ & RAB & $15-\mathrm{O}-\mathrm{q} 11.2 / 2-3$ \\
\hline 80 & $47, \mathrm{XY},+\operatorname{mar}[100 \%]$ & n.a. & $\operatorname{inv} \operatorname{dup}(15)(q 11.2 \sim q 12)$ & FP & 15-O-q11.2 12/1-1 \\
\hline $81^{\mathrm{b}}$ & 47,XY,+mar[?100\%] & n.a. & $\operatorname{inv} \operatorname{dup}(15)(\mathrm{q} 11.2 \sim \mathrm{q} 12)$ & RAB in female partner & 15-O-q11.2 12/1-3 \\
\hline 82 & $47, \mathrm{XY},+\operatorname{mar}[100 \%]$ & n.a. & $\operatorname{inv} \operatorname{dup}(15)(q 11.2 \sim q 13)$ & Oligospermia & $15-\mathrm{CO}-2$ \\
\hline 83 & $47, \mathrm{XY},+\operatorname{mar}[100 \%]$ & n.a. & $\min (15)$ & $\mathrm{RAB}$ & $15-\mathrm{CO}-24$ \\
\hline 84 & 47,XY,+mar[?100\%] & n.a. & $\operatorname{mar}(15)$ & FP & $15-\mathrm{CO}-47$ \\
\hline 85 & $47, \mathrm{XY},+\operatorname{mar}[100 \%]$ & n.a. & inv dup(15) & Oligozoospermia & $15-\mathrm{CO}-64$ \\
\hline 86 & $47, \mathrm{XY},+\operatorname{mar}[100 \%]$ & n.a. & inv dup(15) & Oligozoospermia & $15-\mathrm{CO}-67$ \\
\hline 87 & $47, \mathrm{XY},+\operatorname{mar}[100 \%]$ & n.a. & inv dup(15) & FP & $15-\mathrm{CO}-68$ \\
\hline 88 & $47, \mathrm{XY},+\operatorname{mar}[100 \%]$ & n.a. & inv dup(15) & Severe OAT & $15-\mathrm{CO}-69$ \\
\hline 89 & $47, \mathrm{XY},+\operatorname{mar}[100 \%]$ & n.a. & inv dup(15) & Severe OAT & $15-\mathrm{CO}-70$ \\
\hline 90 & $47, \mathrm{XY},+\operatorname{mar}[100 \%]$ & n.a. & inv dup(15) & Cryptozoospermia & $15-\mathrm{CO}-71$ \\
\hline 91 & $47, \mathrm{XY},+\operatorname{mar}[100 \%]$ & n.a. & inv dup(15) & FP in female partner & $15-\mathrm{CO}-72$ \\
\hline 92 & $47, \mathrm{XY},+\operatorname{mar}[100 \%]$ & n.a. & inv dup(15) & Sperm donor & $15-\mathrm{CO}-73$ \\
\hline 93 & $\begin{array}{l}47, \mathrm{XY},+\operatorname{mar}[60 \%] / \\
46, \mathrm{XY}[40 \%]\end{array}$ & Paternal & $\mathrm{r}(16)$ & $\mathrm{RAB}$ & $16-\mathrm{CO}-4$ \\
\hline 94 & $\begin{array}{l}47, \mathrm{XY},+\operatorname{mar}[67 \%] / \\
46, \mathrm{XY}[33 \%]\end{array}$ & de novo & $\min (17)(: p 11.2->\mathrm{q} 11.1:)$ & Asthenospermia, ICSI & 17-O-p11.2/1-1 \\
\hline 95 & $\begin{array}{l}47, \mathrm{XX},+\operatorname{mar}[58 \%] / \\
46, \mathrm{XX}[42 \%]\end{array}$ & n.a. & $\min (18)(: p 11.21->\mathrm{q} 11.1:)$ & FP, ICSI & 18-O-p11.21/1-1 \\
\hline $96^{\mathrm{b}}$ & $\begin{array}{l}47, \mathrm{XX},+\operatorname{mar}[87 \%] / \\
46, \mathrm{XX}[13 \%]\end{array}$ & de novo & $\begin{array}{l}\operatorname{mar}(20) \text { - for exact } \\
\text { karyotype see below }\end{array}$ & FP & 20-O-p11.21/1-1 \\
\hline 97 & $\begin{array}{l}\text { 47,XY,+mar mat }[4 \%] / \\
46, \mathrm{XY}[96 \%]\end{array}$ & Maternal & $\operatorname{mar}(20)$ & RAB & $20-\mathrm{CO}-1$ \\
\hline 98 & $\begin{array}{l}47, \mathrm{XY},+\operatorname{mar}[80 \%] / \\
46, \mathrm{XY}[20 \%]\end{array}$ & de novo & $\operatorname{mar}(20)$ & Azoospermia & $20-\mathrm{CO}-2$ \\
\hline 99 & $47, \mathrm{XY},+\operatorname{mar}[100 \%]$ & n.a. & $\mathrm{r}(21)(:: \mathrm{p} 11.2->\mathrm{q} 21.1::)$ & RAB in female partner & 21-O-q21.1/2-1 \\
\hline 100 & $47, \mathrm{XX},+\operatorname{mar}[100 \%]$ & n.a. & $\operatorname{inv} \operatorname{dup}(22)(q 11)$ & FP & 22-O-q11/1-1 \\
\hline 101 & $47, \mathrm{XX},+\operatorname{mar}[100 \%]$ & n.a. & $\operatorname{inv} \operatorname{dup}(22)(q 11.1)$ & FP & 22-O-q11.1/1-7 \\
\hline $102^{\mathrm{b}}$ & $47, \mathrm{XX},+\operatorname{mar}[100 \%]$ & n.a. & $\operatorname{inv} \operatorname{dup}(22)(q 11.1)$ & $\mathrm{RAB}$ & 22/O-q11.1/1-8 \\
\hline $103^{\mathrm{b}}$ & $47, \mathrm{XX},+\operatorname{mar}[100 \%]$ & n.a. & $\operatorname{inv} \operatorname{dup}(22)(q 11.1)$ & FP & 22/O-q11.1/1-10 \\
\hline $104^{\mathrm{b}}$ & $47, \mathrm{XY},+\operatorname{mar}[100 \%]$ & n.a. & $\begin{array}{l}\min (22)(\text { pter->q11.1)[5]/ } \\
\operatorname{inv} \operatorname{dup}(22)(\mathrm{q} 11.1)[5] / \\
\mathrm{r}(22)(:: p \operatorname{pter}->\mathrm{q} 11.1:: \mathrm{q} 11.1 \\
->\text { pter::)[2] }\end{array}$ & $\mathrm{RAB}$ in female partner & $21-\mathrm{O}-\mathrm{q} 21.1 / 5-1$ \\
\hline 105 & $47, \mathrm{XY},+\operatorname{mar}[100 \%]$ & n.a. & $\operatorname{inv} \operatorname{dup}(22)$ & FP, ICSI & $22-\mathrm{CO}-7$ \\
\hline 106 & $\begin{array}{l}47, \mathrm{XX},+\operatorname{mar}[? \%] / \\
46, \mathrm{XX}[? \%]\end{array}$ & n.a. & $\mathrm{r}(\mathrm{Y})(:: \mathrm{p} 11.1->? \mathrm{q} 11.2::)$ & FP & 0Y-O-1 \\
\hline
\end{tabular}


Table I. Continued.

\begin{tabular}{|c|c|c|c|c|c|}
\hline $\begin{array}{l}\text { Case } \\
\text { no. }\end{array}$ & GTG-result & $\begin{array}{l}\text { Parental } \\
\text { origin }\end{array}$ & FISH result & Clinical findings & $\begin{array}{l}\text { sSMC no. } \\
\text { according to (8) }\end{array}$ \\
\hline 107 & $47, \mathrm{XX},+\operatorname{mar}[100 \%]$ & Maternal & $\operatorname{dic}(13$ or $21 ; 14)(\mathrm{q} 10 ; \mathrm{q} 10)$ & $\mathrm{RAB}$ & $\begin{array}{l}13 / 21-\mathrm{O}-\mathrm{q} 10 / 4-1 \\
\text { and } 14-\mathrm{O}-\mathrm{q} 10 / 2-1\end{array}$ \\
\hline 108 & $47, \mathrm{XY},+\operatorname{mar}[100 \%]$ & Maternal & $\operatorname{der}(15) \mathrm{t}(9 ; 15)(\mathrm{p} 24 ; \mathrm{q} 11.2)$ & $\mathrm{RAB}$ in female partner & $15-\mathrm{O}-\mathrm{q} 11.2 / 5-1$ \\
\hline 109 & $47, \mathrm{XX},+\operatorname{mar}[100 \%]$ & n.a. & $\operatorname{dic}(Y ; 15)$ & FP & $\begin{array}{l}15-\mathrm{CO}-1 \\
\text { and } 0 \mathrm{Y}-\mathrm{CO}-2\end{array}$ \\
\hline $110^{\mathrm{b}}$ & $\begin{array}{l}47, \mathrm{XY},+\operatorname{mar}[78 \%] / \\
46, \mathrm{XY}[22 \%]\end{array}$ & n.a. & inv dup (acro)(p10) & FP, ICSI & acro-O-4 \\
\hline $111^{\mathrm{b}}$ & $\begin{array}{l}47, X Y,+\operatorname{mar}[25 \%] / \\
46, X Y[75 \%]\end{array}$ & n.a. & inv dup (acro)(p10) & OAT & acro-O-5 \\
\hline
\end{tabular}

${ }^{a}$ The cases are listed according to their chromosomal origin (from 1-22, X,Y). The explanation for the numbering of sSMC cases in (8) is

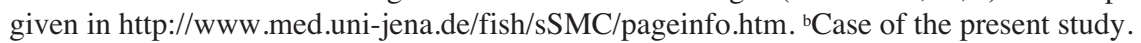

c47 chromosomes: $\operatorname{mar} 1: \min (20)(: 20 p 11.21->20 q 11.21:)[5] /$

$\operatorname{mar} 2: \min (20)(: 20 \mathrm{p} 11.1->20 \mathrm{q} 11.21:)[1] /$

mar3: r(20)(::20p11.1->20q11.21::)[1]/

mar4: $\mathrm{r}(20)(:: 20 \mathrm{p} 11.1->20 \mathrm{q} 11.21:: 20 \mathrm{p} 11.1->20 \mathrm{q} 11.21::)[5] /$

$\operatorname{mar} 5: \min (20)(: 20 \mathrm{p} 11.1->20 \mathrm{q} 11.21:: 20 \mathrm{p} 11.21->20 \mathrm{p} 11.1:)[7] /$

mar6: inv dup(20)(:20p11.1->20p11.21::20q11.21->20p11.1: :20p11.1->20q11.21: :20p11.21->20p11.1:)[1]/

mar7: inv dup(20)(:20q11.1->20q11.21::20p11.21->20q11.1: :20q11.1->20p11.21:)[1]/

mar8: inv dup(20)(:20q11.1->20q11.21: :20p11.21->20q11.1::20q11.1->20p11.1:)[1]

48 chromosomes: $\operatorname{mar} 9: \min (20)(: 20 \mathrm{q} 11.1->20 \mathrm{p} 11.21:: 20 \mathrm{q} 11.21->20 \mathrm{q} 11.1:)+$

mar4: r(20)(::20p11.1->20q11.21::20p11.1->20q11.21::)[1]

FP, fertility problems/unexplained infertility; ICSI, intracytoplasmatic sperm injected treatment patient; n.a., not available; OAT, oligoasthenoteratozoospermia; RAB, repeated abortions. Note: The abbreviation 'min' is applied according to (20) and not to (21).

'patients with fertility problems', however, there might be a tendency for amenorrhea or defined abnormalities in the gametes to appear in correlation with acrocentric sSMC and repeated abortions in correlation with non-acrocentric SSMC (Fig. 3b).

Fertility problems in sSMC carriers and evolutionary effects. Familial as well as de novo sSMC can be associated with fertility problems (Fig. 5). Thus, this observation suggests evolutionary selection against aneuploidy caused by sSMC presence, e.g. similar to that existing in males with karyotype 47,XXY (14). Several mechanisms seem to be involved here. (i) It has been shown repeatedly $(12,15)$ that $\mathrm{SSMC}$ are more likely to be carried forward through the maternal line, thus, selection for gametes without an additional extra chromosome during oogensis can be postulated [for more details see also (12); for centromeric drive see (16)]. (ii) It has also been suggested that any kind of chromosomal aberration can reduce the ability of correct chromosomal pairing during meiosis I (1), which can cause fertility problems especially in males (17). (iii) There are indications that OAT/oligozoospermia is significantly correlated with sSMC presence (7\%), while azoospermia and sSMC are correlated in $<1 \%$ of the corresponding cases (18). (iv) There could also be mechanisms that reduce the percentage of sSMC carrying gametes, as proven for several cases [8 cases: 15-O-q11.1/1-42, 15-Oq11.2/2-3, 15-CO-67 to 72 (19)]. (v) An enhanced rate of repeated abortions in $\mathrm{sSMC}$ carriers or their partners was observed in $22-35 \%$ of the cases collected here (Table I; Fig. 3); in these cases uniparental disomy (UPD) of the sister chromosomes might be a possible explanation, even though such UPD was up to now only proven for de novo sSMC cases. (vi) Finally the influence of epigenetic factors (13) is possible, according to the data presented in Fig. 5b, however, the exact mechanism remains unclear.

Male/female rate in infertile sSMC carriers. As already mentioned, population studies of otherwise healthy persons with unexplained infertility, revealed that there is a detection rate of $0.125 \%$ for sSMC, which is $\sim 2.9$-fold higher than in the normal population (4). Notably, the detection rate was $0.165 \%$ in males and $0.022 \%$ in females (4), i.e. there was a 7.5 -fold difference. This observation is not confirmed by this study, as among those cases in which the origin of the sSMC was determined, there are 71 male and 40 female patients with fertility problems. Thus, both observations are assuredly biased by the heterogeneous reasons which can lead to inclusion in the group 'infertility patients' for cytogenetic study.

\section{Conclusion}

sSMC presence is enhanced in the heterogeneous group 'patients with fertility problems' about 3-fold compared to the normal population. Here for the first time, 111 such patients studied for the chromosomal origin of their sSMC 
revealed that chromosomes 14 and 15 were the most frequently involved. In about $30 \%$ of these cases euchromatic imbalances were caused by the sSMC presence. Unexpectedly, over $50 \%$ of the patients with fertility problems and sSMC presence inherited their marker chromosome from one of their parents. It has to be considered whether this could be in connection with a yet unknown evolutionary selection effect towards the elimination of sSMC from the human gene pool. Thus, sSMC could play an important role in our understanding of the processes involved in chromosome gain and loss during evolution.

\section{Acknowledgements}

This research was supported in parts by the Dr Robert Pfleger-Stiftung, the Ernst-Abbe-Stiftung, the DFG (436 WER 17/1/04, 436 WER 17/5/, WE 3617/2-105, 436 ARM 17/11/06, LI 820/9-1, LI820/11-1), the DAAD and the Evangelische Studienwerk e.V. Villigst.

\section{References}

1. Shah K, Sivapalan G, Gibbons N, Tempest H and Griffin DK: The genetic basis of infertility. Reproduction 126: 13-25, 2003.

2. Uehara S, Hashiyada M, Sato K, Sato Y, Fujimori K and Okamura K: Preferential X-chromosome inactivation in women with idiopathic recurrent pregnancy loss. Fertil Steril 76: 908-914, 2001.

3. Liehr T, Claussen U and Starke H: Small supernumerary marker chromosomes (sSMC) in humans. Cytogenet Genome Res 107: 55-67, 2004.

4. Liehr $\mathrm{T}$ and Weise A: Frequency of small supernumerary marker chromosomes in prenatal, newborn, developmentally retarded and infertility diagnostics. Int J Mol Med 19: 719-731, 2007.

5. Seabright M: A rapid banding technique for human chromosomes. Lancet 2: 971-972, 1971.

6. Nietzel A, Rocchi M, Starke H, Heller A, Fiedler W, Wlodarska I, Loncarevic IF, Beensen V, Claussen U and Liehr T: A new multicolor-FISH approach for the characterization of marker chromosomes: centromere-specific multicolor-FISH (cenMFISH). Hum Genet 108: 199-204, 2001.

7. Starke H, Nietzel A, Weise A, Heller A, Mrasek K, Belitz B, Kelbova C, Volleth M, Albrecht B, Mitulla B, Trappe R, Bartels I, Adolph S, Dufke A, Singer S, Stumm M, Wegner RD, Seidel J, Schmidt A, Kuechler A, Schreyer I, Claussen U, von Eggeling F and Liehr T: Small supernumerary marker chromosomes (SMCs): genotype-phenotype correlation and classification. Hum Genet 114: 51-67, 2003.
8. Liehr T: sSMC-database. http://markerchromosomes.ag.vu or http://www.med.uni-jena.de/fish/sSMC/00START.htm.

9. Liehr T, Starke H, Senger G, Melotte C, Weise A and Vermeesch JR: Overrepresentation of small supernumerary marker chromosomes (SSMC) from chromosome 6 origin in cases with multiple sSMC. Am J Med Genet A 14: 46-51, 2006.

10. Barber JC: Directly transmitted unbalanced chromosome abnormalities and euchromatic variants. J Med Genet 42: 609-629, 2005.

11. Liehr T, Mrasek K, Weise A, Dufke A, Rodriguez L, Martinez Guardia N, Sanchis A, Vermeesch JR, Ramel C, Polityko A, Haas OA, Anderson J, Claussen U, von Eggeling F and Starke H: Small supernumerary marker chromosomes progress towards a genotype-phenotype correlation. Cytogenet Genome Res 112: 23-34, 2006.

12. Liehr T: Familial small supernumerary marker chromosomes are predominantly inherited via the maternal line. Genet Med 8: 459-462, 2006.

13. Eichenlaub-Ritter U, Adler ID, Carere A and Pacchierotti F: Gender differences in germ-cell mutagenesis and genetic risk Environ Res 104: 22-36, 2007.

14. Morel F, Roux C and Bresson JL: Segregation of sex chromosomes in spermatozoa of $46, \mathrm{XY} / 47, \mathrm{XXY}$ men by multicolour fluorescence in-situ hybridization. Mol Hum Reprod 6: 566-570, 2000.

15. Dalpra L, Giardino D, Finelli P, Corti C, Valtorta C, Guerneri S, Ilardi P, Fortuna R, Coviello D, Nocera G, Amico FP, Martinoli E, Sala E, Villa N, Crosti F, Chiodo F, di Cantogno LV, Savin E, Croci G, Franchi F, Venti G, Donti E, Migliori V, Pettinari A, Bonifacio S, Centrone C, Torricelli F, Rossi S, Simi P, Granata P, Casalone R, Lenzini E, Artifoni L, Pecile V, Barlati S, Bellotti D, Caufin D, Police A, Cavani S, Piombo G, Pierluigi M and Larizza L: Cytogenetic and molecular evaluation of 241 small supernumerary marker chromosomes: cooperative study of 19 Italian laboratories. Genet Med 7: 620-625, 2005.

16. Palestis BG, Burt A, Jones RN and Trivers R: B chromosomes are more frequent in mammals with acrocentric karyotypes: support for the theory of centromeric drive. Proc Biol Sci 271: S22-S24, 2004.

17. Paoloni-Giacobino A, Kern I, Rumpler Y, Djlelati R, Morris MA, Dahoun SP: Familial t $(6 ; 21)(\mathrm{p} 21.1 ; \mathrm{p} 13)$ translocation associated with male-only sterility. Clin Genet 58: 324-328, 2000.

18. Mau-Holzmann UA: Somatic chromosomal abnormalities in infertile men and women. Cytogenet Genome Res 111: 317-336, 2005.

19. McNerlan SE, Morrison PJ, McClure N and Nevin NC: A supernumerary chromosome 20 , identified by FISH, in a male with azoospermia - cause or coincidence? Am J Med Genet A 117: 188-190, 2003.

20. Crolla JA: FISH and molecular studies of autosomal supernumerary marker chromosomes excluding those derived from chromosome 15: II. Review of the literature. Am J Med Genet 75: 367-381, 1998.

21. Shaffer LG and Tommerup N (eds): ISCN 2005. An International System for Human Cytogenetic Nomenclature. S Karger, Basel, 2005. 